\title{
Surviving the Agagites: A Postcolonial Reading of Esther 8-9*
}

\author{
JOSHUA Joel Spoelstra (UNIVERSity OF STELlENbosCh)
}

\begin{abstract}
From a postcolonial perspective, the Jews in the book of Esther not only resist against and survive the Agagites, they also re-appropriate colonising impulses from their cultural memory. This article argues that the battles in Esth 8-9* contain several appropriations from holy war in the Deuteronomistic History, and, as a result, the said narrative can be identified as written to fit within the trajectory of the Jews' own imperium. This literary intertextuality is underpinned by three expressions of holy-war language and protocol: fear falling on the Jews' enemies, the Jews refraining from plundering, and the postwar hanging of corpses on trees.
\end{abstract}

Key concepts: Deuteronomistic History, Esther, Haman, Holy War, Mordecai

\section{A INTRODUCTION}

The events of Esth 8-9* (MT) depict the battles between the Jews and the Agagites - the culminated struggle which had been brewing since the initial conflict between Mordecai and Haman in Esth 3. What is intriguing about the warfare in the book of Esther is how it resembles aspects of holy-war in the Deuteronomistic History (DtrH), appropriating its language and protocol. ${ }^{1}$ The purpose of these allusions in the book of Esther, it is hypothesised, is to communicate that through subversive, and then violent resistance against the imperium, the colonised Jews did in fact survive, and even gain ascendancy over the Agagites. In addition, the Jews in Persia are portrayed in the book of Esther as achieving a militaristic victory that is polemically better than that of king Saul, yet not as satisfactory as those under Joshua. Ironically, in order to survive the co-colonised Agagites the colonised Jews must exploit imperial power better than their opponents do (in Esther), thus vicariously reasserting their own imperium from aforetime (in DtrH). Hence, in the book of Esther there is a

* Article submitted: 24/11/2014; accepted 19/02/2015. To cite: Josh J. Spoelstra, "Surviving the Agagites: A Postcolonial Reading of Esther 8-9*," OTE 28/1 (2015): 168-181, DOI: http://dx.doi.org/10.17159/2312-3621/2015/v28n1a11

1 See Gerhard von Rad, Holy War in Ancient Israel (trans. Marva J. Dawn; Grand Rapids: Eerdmans, 1991), esp. 49-51; Tremper Longman III and Daniel G. Reid, God is a Warrior (SOTBT; Grand Rapids: Zondervan, 1995), 33-46; Patrick D. Miller Jr., The Divine Warrior in Early Israel (Cambridge, Mass.: Harvard University Press, 1973). 


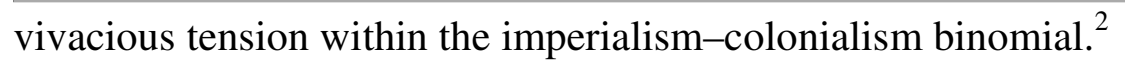

\section{B METHODOLOGY AND APPROACH}

In the pursuit to ascertain what is purported to have taken place in the battles in Esth $8-9 *$ and the significance of its implications, the literary nature of the book of Esther itself must first be defined. The historicity of the book of Esther has long been deliberated ${ }^{3}$ in short, while it has the impression of being historical (e.g. the Persian Empire under King Ahasuerus / Xerxes, ${ }^{4}$ and the greatly elaborated Purim festival [which is still observed to this day] ${ }^{5}$ ) there are many other elements which cannot be factually verified. ${ }^{6}$ The literary nature of Esther, nevertheless, can be determined in large part by its genre; the genre of the book is carnivalesque, ${ }^{7}$ or, similarly, farce. "Farce often employs repetition-of scenes, events, and phrases - and inversions or reversals," notes Adele Berlin, as well as "exaggeration, caricature, ludicrous situations, practical jokes, coincidences, improbabilities, and verbal humor." 9 These stylistic features are pervasive in Esther. As a result, where a fictional story is set in an historical setting or backdrop, the effect is a semi-historical record, something

2 The terminology "binomial," or otherwise "axis," is from Fernando F. Segovia, "Biblical Criticism and Postcolonial Studies: Toward a Postcolonial Optic," in The Postcolonial Biblical Reader (ed. Rasiah S. Sugirtharajah; Malden, Mass.: Blackwell Publishing, 2006), 37-40.

3 For overviews of Esther's historicity see, e.g., Carey A. Moore, Esther (AB 7B; Garden City, N.Y.: Doubleday, 1971), xxxiv-xlvi; Lewis B. Paton, A Critical and Exegetical Commentary on The Book of Esther (ICC; Edinburgh: T \& T Clark, 1976), 64-77; Michael V. Fox, Character and Ideology in the Book of Esther (Columbia, S.C.: University of South Carolina Press, 1991), 131-139; Jon D. Levenson, Esther (OTL; Louisville, Ky.: Westminster John Knox, 1997), 23-27.

4 Herodotus, Books 5-7 (vol. 3 of The Persian Wars; trans. Alfred D. Godley; LCL 119; Cambridge, Mass.: Harvard University Press, 1922); Herodotus, Books 8-9 (vol. 4 of The Persian Wars; trans. Alfred D. Godley; LCL 119; Cambridge, Mass.: Harvard University Press, 1925); Xenophon, Books 1-4 (vol. 1 of Cyropaedia; trans. Walter Miller; LCL 51; Cambridge, Mass.: Harvard University Press, 1914); Xenophon, Books 5-8 (vol. 2 of Cyropaedia; trans. Walter Miller; LCL 51; Cambridge, Mass.: Harvard University Press, 1914).

5 Cf. Fox, Character, 151-152.

6 Moore, Esther, liii, writes, "the Book of Esther has a historical core ... to which have been added legendary and fictional elements ..." See again n. 4 above.

7 Kenneth Craig, Reading Esther: A Case for the Literary Carnivalesque (Louisville, Ky.: Westminster John Knox Press, 1995).

8 So Adele Berlin, Esther (JPSBC; Philadelphia, Pa.: The Jewish Publication Society, 2001), xix.

9 Berlin, Esther, xix; so Carol M. Bechtell, Esther (IBC; Louisville, Ky.: Westminster John Knox Press, 2002), 5. 
similar to historical fiction. ${ }^{10}$ In this rite, it is interesting that the author(s) / redactor(s) of Esther drew on the culturally and historically bound DtrH. ${ }^{11}$

To determine the rationale of appropriating DtrH allusions in the book of Esther, postcolonial biblical criticism shall be employed. As R. S. Sugirtharajah remarks, postcolonial criticism, borrows from "historical-criticism to contemporary literary methods" "but employs them as counter-tools and uses them as an act of disobedience directed against the text and its interpretation."12 Indeed, the diachronic and synchronic analyses most relevant for and embedded in the postcolonial criticism of Esth $8-9 *$ are the traditio-historical and intertextuality methods, respectively. ${ }^{13}$ More specifically, a heritagist reading of postcolonial criticism underpins the paper's hypothesis. Sugirtharajah explicates the heritagist reading is "an attempt by the colonized . . . to retrieve cultural memory from the amnesia caused by colonialism. . . This retrieval takes place sometimes in the form of reinterpretation of stories, myths, and legends as a remembered history of a . . . race, sometimes as intertextual interpolations of quotations, allusions, and references." 14 Certainly, these are the precise motivations at work in the book of Esther.

Thus, the author(s) / redactor(s) of Esther wrote the battle events in such a way as to draw from militaristic stories of the time when Israel was an imperial power to polemically respond to the oppression of the present imperium. Whether or not the characters in Esther are suffering from cultural amnesia via colonialism, there exists a reinterpretation of DtrH stories. The battles of Esth $8-9 *$ aspire to those campaigns led by Joshua, yet the possession of land is unattainable; alternatively, at points the narrative aims at rectifying certain battles under Saul, however much carnage is realised as a consequence. Therefore, the (subversive, violent) resistance and (silent) protest of the Jews in Esther

10 Similarly, Moore, Esther, lii: "Thus when all the evidence is taken together, we conclude that Esther is neither pure fact nor pure fiction: it is a historical novel." Cf. Levenson, Esther, 25; Fox, Character, 144-145.

11 Shemaryahu Talmon, "Wisdom' in the Book of Esther," VT 13/4 (1963): 455, has argued that Esther is an "historicized wisdom-tale." Contra Fox, Character, 143.

${ }_{12}$ Rasiah S. Sugirtharajah, Postcolonial Criticism and Biblical Interpretation (Oxford: Oxford University Press, 2002), 100, 99.

13 For traditio-historical criticism see e.g., Robert A. Di Vito, "Tradition-Historical Criticism," in To Each Its Own Meaning: An Introduction to Biblical Criticisms and their Applications (ed. Steven L. McKenzie and Stephen R. Haynes; rev. ed.; Louisville, Ky.: Westminster John Knox Press, 1999), 90-104. For the methodology of intertextuality, see e.g. Will Kynes, "Intertextuality: Method and Theory in Job and Psalm 119," in Biblical Interpretation and Method: Essays in Honour of John Barton (ed. Katharine J. Dell and Paul M. Joyce; Oxford: Oxford University Press, 2013), 201-213.

14 Sugirtharajah, Postcolonial, 55. 
give way to their struggle for survival, and that survival is oriented within Israel's larger (hi)story.

\section{THE CATALYSING EVENTS OF ESTHER 8-9*}

In Esth 3, one man's grudge against another escalates to a full-scale genocidal onslaught of one clan and the resistant retaliation of the other, in Esth 8-9*. The catalytic events were thus: after Haman's promotion "all the king's servants who were at the king's gate bowed down and did obeisance to Haman; for the king had so commanded concerning him. But Mordecai did not bow down or do obeisance" (Esth 3:2). ${ }^{15}$ Mordecai's consistent omission of genuflection (Esth 3:4)_offensive to Haman and an infraction of the law_-may be seen as a silent protest, an act of defiance on the part of the marginalised; this tactic is one of the few weapons in the arsenal, as it were, of one colonised under the weight of the empire. ${ }^{16}$ Haman's revenge, ${ }^{17}$ possibly because of the near unmitigated power of the empire (Esth 3:8-11), is not met on an individual level alone but encompasses Mordecai's people, the Jews, in a hegemonic and genocidal edict (Esth 3:5-6). ${ }^{18}$ Such is the mounting conflict throughout the book of Esther-indeed, the book of Esther can be seen as a survival text. ${ }^{19}$

Even the introduction of characters underscores the mutual animosity between the people of Mordecai and Haman's people. The protagonists are "a Jew in Susa the citadel whose name was Mordecai, the son of Jair, son of Shimei, son of Kish, a Benjaminite, who had been carried away from Jerusalem among the captives carried away with Jeconiah king of Judah, whom Nebuchadnezzar king of Babylon had carried away" (Esth 2:5-6), and "Hadassah, that is Esther, the daughter of [Mordecai's] uncle" (Esth 2:7a). The antagonist, on the other hand, is "Haman the Agagite, the son of Hammedatha" (Esth 3:1, $10 ; 8: 5 ; 9: 24$ ) or just simply "Haman the Agagite" (Esth 8:3). Quite often affixed to Haman's patronymics is the descriptive phrase "the enemy of [all] the Jews" (Esth 3:10; 8:1; 9:10 [9:24]); accordingly, the "enemies" of the Jews are intended to mean the Agagites (Esth 8:11, 13; 9:1, 5, 16, 22). Dissident and resistant readings within postcolonial criticism reveal, however, that character representation in the book of Esther is often inverted; ${ }^{20}$ for instance, Esther and

15 All biblical citations are from the RSV.

16 Cf. Sugirtharajah, Postcolonial Criticism, 84-85.

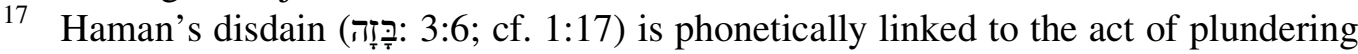

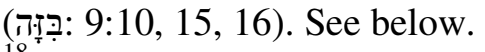

18 See Sugirtharajah, Postcolonial Criticism, 80-81.

19 Itumeleng J. Mosala, "The Implications of the Text of Esther for African Women's Struggle for Liberation in South Africa," in The Postcolonial Biblical Reader (ed. Rasiah S. Sugirtharajah; Malden, Mass.: Blackwell Publishing, 2006), 139-140.

20 'Representation is about construction of the 'other' and at the same time it is also about how such constructions stereotype the identities of both the colonized and the 
Mordecai are both oppressed Jews by high ranking officials in the Persian Empire.

But these two clans, the Jews and Agagites, are not merely enemies in the book of Esther; actually, there appears to be a longevous hostility between these people groups from aforetime. The Agagites likely take their name from Agag, the last remaining survivor of the Amalekites (Num 24:7; 1 Sam 15); if so, ${ }^{21}$ then (king) Agag would be the progenitor of the Agagites in Esther. ${ }^{22}$ Thus, a tenuous connection is made between the Israelites and Amalekites, but one in which Haman as Agagite is illuminated to be a longstanding enemy making palpable such a vengeful edict to destroy all the Jews. ${ }^{23}$

Returning, then, to Haman's hegemony as it concerns the genocidal edict (or, the king's edict via Haman), it allowed all the peoples "to destroy, to slay, and to annihilate all Jews, young and old, women and children" (Esth 3:13[14]). At first Haman and the Agagites had the advantage over the Mordecai and the Jews; next, through peripety (by God?), Esther and Mordecai and the Jews had the advantage over the Agagites unto destruction. The reversal pivoted on whether it was Haman or Esther who could exploit Ahasuerus' imperial power. The king's counter-edict, drafted through the agency of Mordecai and Esther, permitted the Jews "to gather and defend their lives, to destroy, to slay, and to annihilate any armed force of any people or province that might attack them" (Esth 8:11). ${ }^{24}$ The mutual conflict between the two clans in efforts to capitalise on the destruction of the other is expressed by a threefold repetition of death terms:

\begin{tabular}{|c|c|c|}
\hline Esther 3:13 & Esther 7:4 & Esther 8:11 \\
\hline 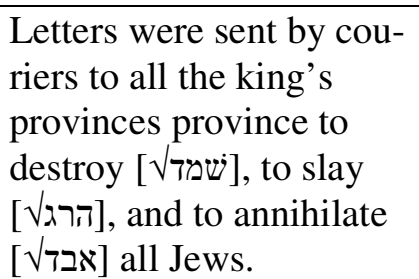 & $\begin{array}{l}\text { "For we are sold, I and } \\
\text { my people, to be } \\
\text { destroyed }[\sqrt{ } \text { שממג], to be } \\
\text { slain }[\sqrt{ }], \text { and to be } \\
\text { annihilated [ אבד ]." }\end{array}$ & 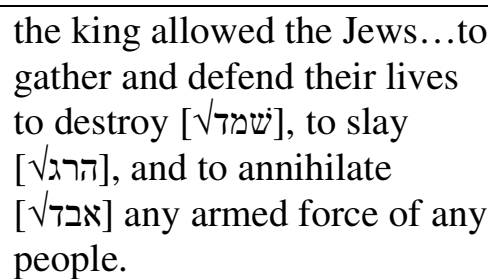 \\
\hline
\end{tabular}

colonizer in such terms as race, class, and gender, and in religious and sexual categories." See Rasiah S. Sugirtharajah, Exploring Postcolonial Biblical Criticism: History, Method, Practice (Malden, Mass.: Wiley-Blackwell, 2012), 161.

21 Paul Haupt, "Critical Notes on Esther," AJSL 24/2 (1908): 124, notes: "From the Greek point of view the Macedonians were northern barbarians, and the Jews regarded the Samaritans as northern barbarians. This explains why H[aman] is called both a Macedonian and a Galgean."

22 Cf. Duane L. Christensen, “Agag," $A B D$ 1: 89. Cf. also Mark J. Fretz, “Agagite," $A B D$ 1: 89-90.

23 See Jon D. Levenson, "Is There a Counterpart in the Hebrew Bible to New Testament Antisemitism," JES 22/2 (1985): 249.

24 Cf. Gerrie Snyman, "The African and Western Hermeneutics Debate: Mimesis, The Book of Esther, and Textuality," OTE 25/3 (2012): 661-663. 
Any one of these verbs would have sufficiently and effectively communicated the force of the edict, yet a tripartite verbal construction is thrice present. ${ }^{25}$ Consequently, a grand battle ensues in Esth $8-9 *$ to the aforesaid timbre.

In what remains it shall be argued that the author(s) / redactor(s) of Esther has portrayed the battles in Esth $8-9 *$ with a Deuteronomistic hue in three particular ways: (1) the report of dread falling upon the people vis-à-vis the Jews and the concomitant vexation of the Jew's enemies; (2) the conspicuous detail of the Jews forfeiting to seize plunder; (3) the curious symbolic gesture of the Jews hanging the Agagite leaders on a tree. In the end, the narrative evokes holy-war proclivities and protocol in order to demonstrate the recapitulation of Israel as its own imperium, overthrowing tribes and nations and establishing its own rule, with God's agency.

\section{THE EVENTS OF ESTHER 8-9*}

\section{$1 \quad$ Dread and Vexation}

As the sands begin to shift, the Jews are portrayed as gaining ascendency over the Agagites. This is demonstrated in the narrative, in part, by the threefold statement of dread or fear (נפלר) (נפר) ${ }^{26}$ falling un the Jews' adversaries (Esth $8: 17 ; 9: 2,3) .{ }^{27}$ The effect of this descending dread is that the enemies of the Jews could not stand against the Jews (Esth 9:2), other peoples aided the Jews (Esth 9:3), and some even identified themselves as Jews (Esth 8:17). In DtrH, YHWH is the source of fear / dread in the context of warfare (Deut 2:25; 11:25; 1 Sam 11:7; see also Exod 15:16; Ps 105:38); and the effect of this divinely induced dread is not only victory over the enemy but for the purpose of the (re)sequestration of the land.

A concept akin to fear falling upon enemies is one found in the summary statement of Esth 9:24: "Haman the Agagite, the son of Hammedatha, the enemy of all the Jews, had plotted against the Jews to destroy them, and had

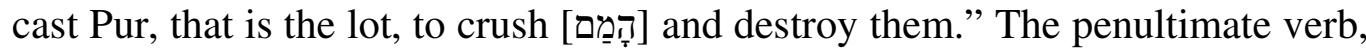
המַָם means to bring into motion and confusion, to confuse, disturb, or vex. ${ }^{28}$ By utilising this rare term the peripety is epitomised: Haman is vexed-it is actually he and his people who are destroyed by the book's end. הכַָם finds striking reverberation in DtrH, used six times (Deut 2:15; Josh 10:10; Judg 4:15; 1

25 The terms שמדר also occur in Deut 4:26; 7:24; 28:20. Also, הרג and and

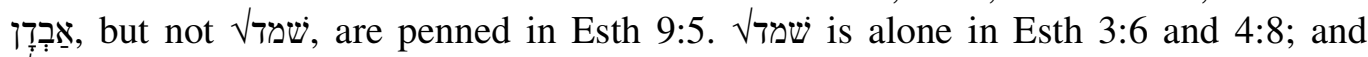
שמד is twice in Esth 9:24.

26 HALOT 2:922-923; BDB: 808.

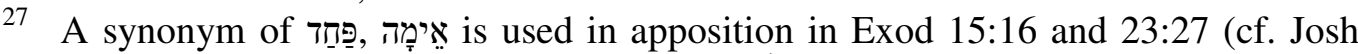
2:9); אִימָה is also employed in conjunction with המם in 23:27. See below.

28 HALOT 1:251; BDB: 243. 
Sam 7:10; 2 Sam 22:15 / Ps 18:15; cf. Exod 14:24). In these occurrences said action is also exclusively attributed to YHWH in the context of battle ${ }^{29}$ and, again, the purpose of such a victory is to covey that it is YHWH who fights on behalf of Israel (holy-war) to give her the land.

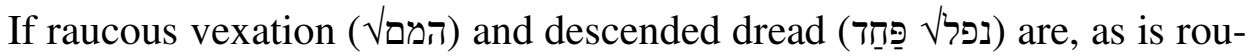
tinely the case in DtrH, from YHWH to achieve military defeat of the enemy, then can the same be inferred from the unmentioned God of the Jewish people in the book of Esther? Even if so, the land is still in possession of the Persians. Consequently, it appears this language is appropriated in order to demonstrate the Jews' victory over the Agagites, perhaps hinting that it was YHWH who helped them in battle, yet not quite to the culminated effect as with Joshua and some of the judges in the conquest to sequester land. ${ }^{30}$

\section{Abstaining from Plunder}

Though the tables had turned after Haman's ulterior motives were unveiled, the demagogue's nefarious edict still circulated throughout the Persian Empire which permitted, even encouraged, the destruction of the Jewish people. In efforts to counteract Haman's edict, Mordecai and Esther also wrote an edict, with the king's authority, validating the Jews to take protective measures in the forthcoming battle. Thus on the thirteenth and fourteenth day of Adar war broke out between the Agagites and Jews in the urban and rural parts of the kingdom alike — and the Jews were victorious.

Both edicts had the endorsement that the militaristic aggressors could also be permitted to take plunder from their opponents. That was stated in Haman's edict because of the desired maltreatment of the Jews (Esth 3:13), while Esther and Mordecai wrote the same in order to thoroughly (i.e., pointfor-point) countermand the original edict (Esth 8:11). ${ }^{31}$ Yet, despite the legal permissibility to seize plunder, the Jews expressly did not. The phrase , "but they laid no hand[s] on the plunder," occurs thrice verbatim in the narrative (Esth 9:10 [15, 16]). ${ }^{32}$ The deference of plundering a fallen enemy evokes the aspiration to observe holy-war protocol. ${ }^{33}$ Deuteronomy

29 In Deut 2:15 YHWH actually crushes, or brings vexation upon the rebellious generation of Israelites.

30 Cf. Jonathan Grossman, Esther: The Outer Narrative and the Hidden Reading (Siphrut 6; Winona Lake, Ind.: Eisenbrauns, 2011), 186-188.

31 For Mordecai and Esther as dual agents of edict writing, see Grossman, Esther, 32-35.

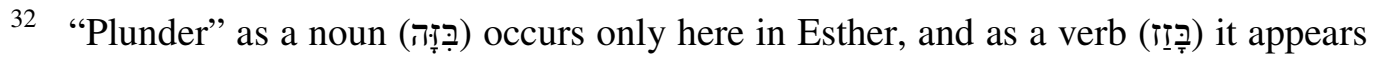
in Esth 3:13 and 8:11; see also Deut 2:35; 3:7; 20:14; Josh 8:2, 27; 11:14; 1 Sam 14:36; 2 Kgs 7:16. Cf. Bechtell, Esther, 73-74; Mosala, "Implications," 139.

33 For an ironical interpretation of this point, see Carolyn J. Sharp, Irony and Meaning in the Hebrew Bible (Indianapolis, Ind.: Indiana University Press, 2009), 69. 
13:18 (MT) states, "None of the devoted things shall cleave to your hand; that the LORD may turn from the fierceness of his anger, and show you mercy, and have compassion on you, and multiply you, as he swore to your fathers." 34 To prevent any banned / devoted things from "clinging" to their hands, the Jews in Persia did not even touch it! $!^{35}$ As a consequence, the surviving Jewish diaspora may be seen as adhering to God's stipulations over against king Ahaseurus' edict.

Beyond adhering to holy-war protocol in general, the Jews in Persia, as portrayed in Esth 8-9*, may be interpolated as redeeming the failure of Israel under king Saul who stole plunder from God (1 Sam 15). ${ }^{36}$ Mordecai, furthermore, may here be perceived as Israel's kinsman redeemer, in particular, rectifying king Saul's folly. First and foremost, Mordecai (Esth 2:5) and Saul (1 Sam 9:21) are not only Benjaminites-they are both from the family of Kish! Second, by dictating the edict Mordecai is functionally the spearhead aggressor of the battles (albeit in a vicarious fashion) for the Jews to retaliate against their enemies; he is thus seen as paralleling Saul who, as king, was the leader in battle. Consequently, the act of committing the banned things, the spoil to God is a sign that would indicate Israel's enemy is destroyed.

\section{$3 \quad$ Hung on a Tree}

Haman's wife, Zeresh, ${ }^{37}$ and Haman's friends advised him to kill Mordecai by use of, what is commonly translated, a "gallows" (Esth 2:23; 5:14; 6:4; 7:9, 10; $8: 7 ; 9: 13,25) .{ }^{38}$ This so-called gallows is simply y․, "tree" or "wood,"39 and denotes here a wooden pole or beam. In fact, the most popular means of execution in the Persian Empire was the impalement of persons on a vertical stake. This is recorded by Herodotus, both in general terms (III.125, 158) and regarding Xerxes' specific usage (IV.43); ${ }^{40}$ and, impalement even finds biblical

34 חֶרֶ ("devoted thing" or "ban" [BDB: 356]) occurs here, in DtrH, as well as Deut $2: 34 ; 3: 6 ; 7: 2$, 26; 13:16; 20:17; Josh 2:10; 6:17-18, 21; 7:1, 11-13, 15; 8:26; 10:1, 28, 35, 37, 39-40; 11:11-12, 20-21; 19:38; 22:20; Judg 1:17; 21:11; 1 Sam 15:3, 8-9, 15, 18, 20-21; 1 Kgs 9:21; 20:42; 2 Kgs 19:11.

35 Grossman, Esther, 191, 226.

36 So Berlin, Esther, 85: "Saul took booty from the Amalekites although he was forbidden to do so; but the Jews of Persia do not take booty from their enemies even though they are entitled to do so ... this reversal in reference to booty wipes away the sin of the house of Saul." Cf. Diana Edelman, "Saul's Battle Against Amaleq (1 Sam. 15)," JSOT 35 (1986): 71-84. Cf. also Moore, Esther, 87-88.

37 "Though the conflict began as one between two men, Mordecai and Haman, it is now two women, Esther and Zeresh, who are determining the action." See Levenson, Esther, 92.

38 E.g., ESV, NIV (1984), RSV, NASB, NLT, NRS. So also Paton, Esther, 240.

39 BDB:781; HALOT 1:863-864.

40 Herodotus, Books 3-4 (vol. 2 of The Persian Wars; (trans. A. D. Godley; LCL 118; Cambridge, Mass.: Harvard University Press, 1921). 
citation in Ezra 6:11 (Ezra-Nehemiah, of course, also set in the Persian milieu): "Also I [Dairus] make a decree that if any one alters this edict, a beam [Yy] shall be pulled out of his house, and he shall be impaled upon it, and his house shall be made a dunghill."

The עy, moreover, evokes the following Deuteronom(ist)ic curse: "And if a man has committed a crime punishable by death and he is put to death, and

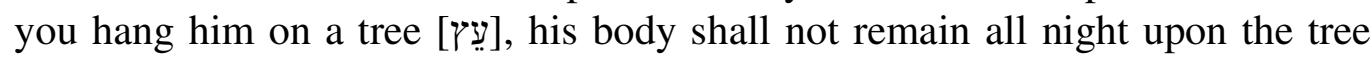
[Yy], but you shall bury him the same day, for a hanged man is accursed by God" (Deut 21:22-23a). This law is occasionally implemented in Israelite warfare, as evidenced in Joshua's militaristic campaign of Canaan, namely, the Promised Land. On two separate occasions (Josh 8:29; 10:26-27) Joshua hung the corpses of kings (the king of Ai and the five kings of the Amorites) on trees (Yy), took down their dead bodies before sunset, and heaped a pile of rocks over those corpses. This general model is enacted in the book of Esther too. ${ }^{41}$

In Esther, Haman was ironically hanged on his own execution tree. ${ }^{42}$ Shortly thereafter the prearranged day of battle ensued and the Jews killed "five hundred men and also the ten sons of Haman" (Esth 9:12a). However, it appears not enough for the bodies of Haman's ten sons to merely be left on the battlefield. Esther convinced Ahaseurus to issue another edict not only permitting the Jews to defend themselves the subsequent day, but it also included the proviso to "let the ten sons of Haman be hanged on the gallows" (Esth 9:13). Thus, those ten corpses were also hung, or impaled, on the tree (עy), joining their father's (Esth 9:13-14, 25).

Haman's עي is purported to be 50 cubits in height (Esth 5:14; 7:9); and there is much debate as to whether this is a literalistic measurement or a hyperbolic one. ${ }^{44}$ Targumic tradition favors the former; the meturgeman explicates:

all of them were hung on the same pole, which contained four cubits for eleven corpses - the body is three cubits during life, expanding a

41 So Jeffery H. Tigay, Deuteronomy (JPSBC; Philadelphia, Pa.: The Jewish Publication Society, 1996), 198, 382 n.59.

42 Previously in the book of Esther the two assassins whom Mordecai exposed were hanged on a tree (Esth 2:23). See Frederic Bush, Ruth / Esther (WBC 9; Dallas, Tex.: Word Books Publishers, 1996), 373.

43 The replication of condoned genocide has disturbed South African scholars particularly. See Mmadipoane (Ngwana 'Mphahlele) Masenya, "Esther and Northern Sotho Stories: An African-South African Woman's Commentary," in Other Ways of Reading: African Women and the Bible (Atlanta: Society of Biblical Literature, 2001), 31, 42; Sarojini Nadar, "Gender, Power, Sexuality and Suffering Bodies in the Book of Esther: Reading the Characters of Esther and Vashti for the Purpose of Social Transformation," OTE 15/1 (2002): 127-128; Gerrie Snyman, "Narrative Rationality, Morality, and Readers' Identification," OTE 15/1 (2002): 182-186.

44 For exaggeration see Moore, Esther, 60; Levenson, Esther, 93; Berlin, Esther, 55. 
cubit after death; thus it spans four cubits. Thus the corpses of Haman's ten sons and Haman's corpse occupied forty-four cubits, which left six cubits from the tree (as the tree was fifty cubits high), as well as three cubits sunk in the ground and three cubits from the ground to the lowest corpse (on the gallows). ${ }^{45}$

Regardless of the exact positioning of the eleven Agagites on the wood beam, ultimately the visual statement was made to all: ${ }^{46}$ it is not the Jews who were to be cursed, according to Deuteronom(ist)ic tradition, rather it is the Agagites who are cursed. ${ }^{47}$

At this juncture too Mordecai may be imaged as Israel's kinsmen redeemer vis-à-vis king Saul. Mordecai, through the agency of Esther and exploiting imperial authority, ${ }^{48}$ ordered the hanging of Haman's ten sons (Esth 9:13-14, 25) —not just for those corpses to be left fallen and exposed. ${ }^{49}$ It is feasible that Haman's sons were hung on the cursed tree with Haman, furthermore, in order to counteract, or redeem the death and hanging of king Saul and his sons. In the wake of the battle against the Philistines in 1 Sam 31, the lifeless bodies of Saul and his three sons were hung on the wall of Bethshan. Later, in 2 Sam 21, when David seeks to atone for the unjust killing of the Gibeonites on behalf of Saul, that Amorite remnant exacted justice by hanging seven of Saul's sons on trees. This count totals ten sons of Saul who were hung, by one means or another, in relation to Haman's ten sons who were likewise hung. ${ }^{50}$ Thus, even though none of Saul's sons were killed by Agagites, the law of talion (ten for ten) is provocative. Consequently, the author(s) / redactor(s) of Esther appears to have portrayed Mordecai and Esther as vindicating Israel's first king, and Israel in general, by describing the battle events with Deuteronomistic verbiage and inserting the purported events of Esth 8-9* within the trajectory of DtrH, especially as it concerns warfare and the heritage of the Hebrew people (Israelites / Jews).

45 Bernard Grossfeld, The Two Targums of Esther (ArBib 18; Collegeville, Minn.: Liturgical Press, 1991), 190 n.5; cf. Duane L. Christensen, Deuteronomy 21:10-34:12 (WBC 6B; Nashville, Ky.: Thomas Nelson Publishers, 2002), 489.

46 Indeed, it is a "public warning." See Richard D. Nelson, Deuteronomy: A Commentary (OTL; Louisville, Ky.: Westminster John Knox Press, 2002), 262. Whereas the Persians put people on wood beams to kill them, the Israelites / Jews put dead people on trees; nevertheless, the both had the implied message of warning or curse on the victims and would-be violators.

47 Levenson, Esther, 122 (93) and Berlin, Esther, 86, merely speak in terms of "disgrace."

48 See again, Grossman, Esther, 32-35.

49 Cf. Sharp, Irony and Meaning, 74.

50 Berlin, Esther, 86; Yitzhak Berger, "Esther and Benjaminite Royalty: A Study of Inner-Biblical Allusion," JBL 129/4 (2010): 635. 


\section{Spoelstra, "Surviving the Agagites," OTE 28/1 (2015): 168-181}

\section{E CONCLUSION}

In conclusion, the battles of Esth 8-9* are presented as portending holy-war by virtue of the vexation and fear which fell on the Jews' enemies, the datum of the Jews not touching the plunder, and the cursed connoting position in which the bodies of Haman and his ten sons hung. The author(s) / redactor(s) of Esther appropriated intentionally, diachronically, and dissonantly from DtrH in shaping the account of the battles. From a postcolonial (biblical criticism) perspective, one reason the author(s) / redactor(s) of Esther drew so heavily upon DtrH when depicting the battles of Esth 8-9* is to catalyse remembrance of Israel as its own colonising imperium, wherein the settlement and securing of the land materialised with God fighting on behalf of God's people; and, there are both sterling (Joshua) and substandard (Saul) examples from Israel's tradition history with which to interact and from which to interpolate.

By establishing a connection with this set of cultural memories, the Jews in Esther are portrayed committed to efforts of resistance and the brutality of survival. If one colonised people (Agagites) could suppress another colonised people (Jews) to the point of destruction by means of exploiting the hegemonic powers of the imperium, then the inverse could also transpire. ${ }^{51}$ In the end, while the colonised Jews resist and survive the co-colonised Agagites, liberation is not finally realised-for, Persian imperialism still prevails. ${ }^{52}$ Nevertheless, some redemptive interpolation of history tradition is recognised by the author(s)/redactor(s) in the book of Esther.

\section{BIBLIOGRAPHY}

Bechtell, Carol M. Esther. Interpretation: A Biblical Commentary for Teaching and Preaching. Louisville, Ky.: Westminster John Knox Press, 2002.

Berger, Yitzhak. "Esther and Benjaminite Royalty: A Study of Inner-Biblical Allusion." Journal of Biblical Literature 129/4 (2010): 625-644.

Berlin, Adele. Esther. The Jewish Publication Society Bible Commentary. Philadelphia, Pa.: The Jewish Publication Society, 2001.

Brown, Francis, Samuel R. Driver, and Charles A. Briggs. Hebrew and English Lexicon of the Old Testament, with an Appendix Containing the Biblical

51 Gerrie Snyman, "Race in South Africa: A Hidden Transcript Turned Public? The Problem of Identifying with Esther/Mordecai or Haman in the Book of Esther," Scriptura 84 (2003): 450, states: "One ramification deserving attention is that which the story of Esther illustrates, namely the possibility of mutating into one's former adversary, the oppressed becoming the oppressor." Cf. further, Gerrie Snyman, "Sensed Fittingness between Act and Consequence: The Last Acts of Esther in the Book of Esther and Grace in the Film Dogville," HTS Teologiese Studies / Theological Studies 69/1 (2013); Art. \#1972, 9 pages; DOI: 10.4102/hts.v69i1.1972; Rasiah S. Sugirtharajah, The Bible and the Third World: Precolonial, Colonial and Postcolonial Encounters (Cambridge: Cambridge University Press, 2001), 246.

52 For liberation hermeneutics, see Sugirtharajah, Postcolonial, 112-122. 
Aramaic. Peabody, Mass.: Hendrickson, 2006.

Bush, Frederic. Ruth/Esther. Word Biblical Commentary 9. Dallas, Tex.: Word Books, 1996.

Christensen, Duane L. "Agag." Page 89 in vol. 1 of Anchor Bible Dictionary. Edited by David N. Freedman. New York: Doubleday, 1998. Deuteronomy 21:10-34:12. Word Biblical Commentary 6B. Nashville, Ky.: Thomas Nelson Publishers, 2002.

Craig, Kenneth. Reading Esther: A Case for the Literary Carnivalesque. Louisville, Ky.: Westminster John Knox Press, 1995.

Di Vito, Robert A. "Tradition-Historical Criticism." Pages 90-104 in To Each Its Own Meaning: An Introduction to Biblical Criticisms and their Applications. Edited by Steven L. McKenzie and Stephen R. Haynes. Rev. ed. Louisville, Ky.: Westminster John Knox Press, 1999.

Edelman, Diana. "Saul's Battle Against Amaleq (1 Sam. 15)." Journal for the Study of the Old Testament 35 (1986): 71-84.

Fox, Michael V. Character and Ideology in the Book of Esther. Columbia, S.C.: University of South Carolina Press, 1991.

Fretz, Mark J. “Agagite.” Pages 89-90 in vol. 1 of The Anchor Bible Dictionary. Edited by David N. Freedman. New York: Doubleday, 1998.

Grossfeld, Bernard. The Two Targums of Esther. Aramaic Bible 18. Collegeville, Minn.: Liturgical Press, 1991.

Grossman, Jonathan. Esther: The Outer Narrative and the Hidden Reading.

Siphrut 6. Winona Lake, Ind.: Eisenbrauns, 2011.

Haupt, Paul. "Critical Notes on Esther." The American Journal of Semitic Languages and Literatures 24/2 (1908): 97-186.

Herodotus. Books 3-4. Volume 2 of The Persian Wars. Translated by Alfred D. Godley. Loeb Classical Library 118. Cambridge, Mass.: Harvard University Press, 1921.

. Books 5-7. Volume 3 of The Persian Wars. Translated by Alfred D. Godley. Loeb Classical Library 119. Cambridge, Mass.: Harvard University Press, 1922.

. Books 8-9. Volume 4 of The Persian Wars. Translated by Alfred D. Godley. Loeb Classical Library 119. Cambridge, Mass.: Harvard University Press, 1925.

Koehler, Ludwig and Walter Baumgartner. The Hebrew and Aramaic Lexicon of the Old Testament. 2 volumes. London: Brill, 2001.

Kynes, Will. "Intertextuality: Method and Theory in Job and Psalm 119." Pages 201-213 in Biblical Interpretation and Method: Essays in Honour of John Barton. Edited by Katharine J. Dell and Paul M. Joyce. Oxford: Oxford University Press, 2013.

Levenson, Jon D. "Is There a Counterpart in the Hebrew Bible to New Testament Antisemitism." Journal of Ecumenical Studies 22/2 (1985): 242-260.

. Esther. Old Testament Library. Louisville, Ky.: Westminster John Knox, 1997.

Longman III, Tremper and Daniel G. Reid. God is a Warrior. Studies in Old Testament Biblical Theology. Grand Rapids: Zondervan, 1995. 
Masenya, Mmadipoane (Ngwana 'Mphahlele). "Esther and Northern Sotho Stories: An African-South African Woman's Commentary.” Pages 27-49 in Other Ways of Reading: African Women and the Bible. Atlanta: Society of Biblical Literature, 2001.

Miller Jr., Patrick D. The Divine Warrior in Early Israel. Cambridge, Mass.: Harvard University Press, 1973.

Moore, Carey A. Esther. Anchor Bible 7B. Garden City, N.Y: Doubleday, 1971. Mosala, Itumeleng J. "The Implications of the Text of Esther for African Women's Struggle for Liberation in South Africa." Pages 134-141 in The Postcolonial Biblical Reader. Edited by Rasiah S. Sugirtharajah. Malden, Mass.: Blackwell Publishing, 2006.

Nadar, Sarojini. "Gender, Power, Sexuality and Suffering Bodies in the Book of Esther: Reading the Characters of Esther and Vashti for the Purpose of Social Transformation." Old Testament Essays 15/1 (2002): 113-130.

Nelson, Richard D. Deuteronomy: A Commentary. Old Testament Library. Louisville, Ky.: Westminster John Knox Press, 2002.

Paton, Lewis B. A Critical and Exegetical Commentary on The Book of Esther. International Critical Commentary. Edinburgh: T \& T Clark, 1976.

Segovia, Fernando F. "Biblical Criticism and Postcolonial Studies: Toward a Postcolonial Optic.” Pages 33-44 in The Postcolonial Biblical Reader. Edited by Rasiah S. Sugirtharajah. Malden, Mass.: Blackwell Publishing, 2006.

Sharp, Carolyn J. Irony and Meaning in the Hebrew Bible. Indianapolis, Ind.: Indiana University Press, 2009.

Snyman, Gerrie. "Narrative Rationality, Morality, and Readers' Identification." Old Testament Essays 15/1 (2002): 179-199. "Race in South Africa: A Hidden Transcript Turned Public? The Problem of Identifying with Esther/Mordecai or Haman in the Book of Esther." Scriptura 84 (2003): 438-452.

. "The African and Western Hermeneutics Debate: Mimesis, The Book of Esther, and Textuality." Old Testament Essays 25/3 (2012): 657-684. . "Sensed Fittingness between Act and Consequence: The Last Acts of Esther in the Book of Esther and Grace in the Film Dogville." HTS Teologiese Studies / Theological Studies 69/1 (2013). Art. \#1972. 9 pages. DOI: 10.4102/hts.v69i1 .1972.

Sugirtharajah, Rasiah S. The Bible and the Third World: Precolonial, Colonial and Postcolonial Encounters. Cambridge: Cambridge University Press, 2001.

Postcolonial Criticism and Biblical Interpretation. Oxford: Oxford University Press, 2002. . Exploring Postcolonial Biblical Criticism: History, Method, Practice. Malden, Mass.: Wiley-Blackwell, 2012.

Talmon, Shemaryahu. "'Wisdom' in the Book of Esther." Vetus Testamentum 13/4 (1963): 419-455.

Tigay, Jeffery H. Deuteronomy. The Jewish Publication Society Bible Commentary. Philadelphia, Pa.: The Jewish Publication Society, 1996. 
Von Rad, Gerhard. Holy War in Ancient Israel. Translated by Marva J. Dawn. Grand Rapids: Eerdmans, 1991.

Xenophon. Books 1-4. Volume 1 of Cyropaedia. Translated by Walter Miller. Loeb Classical Library 51. Cambridge, Mass.: Harvard University Press, 1914.

. Books 5-8. Volume 2 of Cyropaedia. Translated by Walter Miller. Loeb Classical Library 51. Cambridge, Mass.: Harvard University Press, 1914.

Rev. Dr. Joshua Joel Spoelstra, Research Associate at Department of Old and New Testament, University of Stellenbosch, Stellenbosch 7600, South Africa. Email: josh.spoelstra@gmail.com. 